\title{
Development of a Nested Quantitative Real-Time PCR for Detecting Phytophthora cinnamomi in Persea americana Rootstocks
}

J. Engelbrecht, Department of Microbiology and Plant Pathology, Forestry and Agricultural Biotechnology Institute, and T. A. Duong and N. van den Berg, Department of Genetics, Forestry and Agricultural Biotechnology Institute, University of Pretoria, Pretoria, South Africa

\begin{abstract}
Engelbrecht, J., Duong, T. A., and van den Berg, N. 2013. Development of a nested quantitative real-time PCR for detecting Phytophthora cinnamomi in Persea americana rootstocks. Plant Dis. 97:1012-1017.

Phytophthora cinnamomi causes Phytophthora root rot (PRR) in avocado (Persea americana), an important disease that causes severe economic losses to the avocado industry globally. To date, no PRR-resistant avocado rootstock variety has been discovered, although certain rootstock varieties have been shown to be more tolerant than others. In this study, we developed an accurate, low cost assay for in planta quantification of $P$. cinnamomi to evaluate disease tolerance. A nested realtime polymerase chain reaction assay was developed to sensitively detect pathogen DNA in plant tissues. Root samples from a highly tolerant (Dusa) and less tolerant (R0.12) rootstock were collected at 0 ,

3, 7, 14, and 21 days after inoculation with P. cinnamomi and used for pathogen quantification. Nested primers developed in this study were specific and sensitive and could detect $P$. cinnamomi in root tissues. The amount of $P$. cinnamomi quantified in roots was significantly higher in the less-tolerant R0.12 plants when compared with the highly tolerant Dusa plants at all time points. This study has confirmed the known status of disease tolerance of Dusa and R0.12 avocado rootstocks in a quantitative manner and provides a reliable molecular tool to assist with industry breeding programs for the selection of PRRresistant avocado rootstock varieties.
\end{abstract}

Phytophthora root rot (PRR) is an important disease of avocado caused by the oomycete Phytophthora cinnamomi Rands. It has resulted in severe crop losses in most avocado-producing countries around the globe. The first symptoms are brown to black brittle roots which develop after a brief latent period. Thus far, pathogen quantification of $P$. cinnamomi in woody hosts such as avocado has not yet been attempted.

Traditionally, $P$. cinnamomi detection is based on the microscopic identification of the pathogen after culturing on selective media. However, pathogen quantification by these methods is not entirely reliable because calculations of pathogen biomass by microscopy are laborious and results can differ greatly between investigators (11). Chemical methods such as fatty acid ergosterol and carbohydrate chitin are used to determine the amount of a specific biomolecule either present within pathogen cells or released into the environment $(5,15)$. Although widely implemented and not as laborious as microscopy, these methods lack specificity and become problematic when field samples are processed and required sample size is high.

In recent years, several techniques have been developed to enhance the detection of $P$. cinnamomi (4). Although conventional polymerase chain reaction (PCR) has been useful for numerous Phytophthora spp., it has not been successful when low levels of target DNA, as with latent infections, are encountered. Most importantly, conventional PCR is not quantitative. In contrast, quantitative real-time PCR (qPCR) allows fast, reliable, and accurate detection and quantification of plant pathogens $(8,10)$. Sensitivity

Corresponding author: N. van den Berg,

E-mail: Noelani.VanDenBerg@up.ac.za

Accepted for publication 6 February 2013.

http://dx.doi.org/10.1094/PDIS-11-12-1007-RE

(C) 2013 The American Phytopathological Society of qPCR can be greatly enhanced by implementing a nested approach in which a first round of amplification is carried out with conventional PCR and the resulting product is then quantified in a second step by real-time PCR. With nested PCR, two primer pairs are designed based on the sequence of a target gene, one of which is nested within the other. Specificity of real-time and real-time nested PCR can be assessed by gel electrophoresis, melting curves, and sequencing (10).

The degree of pathogen colonization within a plant may correlate with resistance or susceptibility to a pathogen. In such cases, real-time PCR is an ideal tool for detecting differences in host resistance or susceptibility. Qi and Yang (12) were able to show that resistance to rice blast, caused by Magnaporthe grisea, could be accurately evaluated with real-time PCR analysis for the pathogen. By the time lesion development became visible, M. grisea was 80 times higher in a susceptible compared with a resistant rice cultivar. Another study on alfalfa indicated significant correlations between the amount of Phytophthora medicaginis and the severity of disease it caused in this host (14). We developed a nested qPCR method for in planta quantification of $P$. cinnamomi in two avocado rootstocks displaying different levels of tolerance to PRR. This assay confirmed the known phenotypic tolerance levels of available avocado rootstocks to PRR and, therefore, provides a molecular tool that can be used in avocado breeding programs to streamline and fast-track the selection of rootstocks with high levels of PRR tolerance in a quantitative manner.

\section{Materials and Methods}

Phytophthora isolates and plant materials. The P. cinnamomi isolate used for infection assays was provided by Westfalia Technological Services (WTS), situated in Tzaneen, Limpopo, South Africa. In addition, primer specificity was assessed against 21 Phytophthora spp. and 12 P. cinnamomi isolates selected from different geographical locations (Table 1). Nine-month-old avocado plants of two commercial rootstocks, Dusa (highly tolerant) and R0.12 (less tolerant), were also provided by WTS for in planta experiments. 
Preparation of zoospore suspension. $P$. cinnamomi was first grown on V8 agar plates $(50 \mathrm{ml}$ of filtrated V8 juice, $0.5 \mathrm{~g}$ of $\mathrm{CaCO}_{3}, 20 \mathrm{~g}$ of agar, and distilled water $\left[\mathrm{dH}_{2} \mathrm{O}\right]$ added to make up 1 liter, autoclaved at $121^{\circ} \mathrm{C}$ for $15 \mathrm{~min}$ ) for 5 days. Small agar blocks ( 10 by $5 \mathrm{~mm}$ ) containing mycelia were cut from the actively growing margin of the plates and transferred onto empty $90-\mathrm{cm}-$ diameter petri plates, to which $25 \mathrm{ml}$ of $2 \% \mathrm{~V} 8$ broth $(20 \mathrm{ml}$ of filtrated V8 juice and $0.2 \mathrm{~g}$ of $\mathrm{CaCO}_{3}$ in 1 liter of $\mathrm{dH}_{2} \mathrm{O}$ ) was added and incubated for 3 days at room temperature (approximately $25^{\circ} \mathrm{C}$ ). The broth was removed and agar blocks containing mycelia were rinsed three times with sterilized $\mathrm{dH}_{2} \mathrm{O}$, after which $25 \mathrm{ml}$ of Whatman 1-mm-filtered stream water was added to each plate. Plates were incubated for 2 to 3 days at room temperature under UV light. Sporangia formation was monitored during this incubation period and, once sufficient mature sporangia were ob- served, the plates were cold shocked by incubating at $4{ }^{\circ} \mathrm{C}$ for 45 min, after which they were removed and left at room temperature for $1 \mathrm{~h}$ to stimulate zoospore release. The zoospore suspension was decanted from the plates, pooled together, and used for inoculation.

Inoculation and sample collection. Avocado roots of two rootstocks (Dusa and R0.12) were submerged for an hour in a 5-liter container containing zoospore suspension at a concentration of 7.2 $\times 10^{4}$ zoospores/ml (mock-inoculated plants were submerged in sterile water), after which they were transplanted into 1.5-liter plastic bags filled with perlite (Chemisphere Technologies). Once transplanted, the zoospore suspension that was used to infect was divided into even portions and added to treated plants (50 $\mathrm{ml} /$ plant). Root tissue was collected at $0,3,7,14$, and 21 days post infection (dpi). Root material from three plants per rootstock was harvested per time point, snap-frozen in liquid nitrogen, ground to

Table 1. Isolates of Phytophthora spp. used in this study to confirm the specificity of the nested primers designed ${ }^{a}$

\begin{tabular}{|c|c|c|c|c|}
\hline Species & Host & Location & CMW & $\begin{array}{l}\text { PCR } \\
\text { result }\end{array}$ \\
\hline Phytophthora cinnamomi & Persea americana & South Africa, Limpopo, Tzaneen & & + \\
\hline Phytophthora cinnamomi & Lupinus angustifolius & Australia, NSW, Caboolture & 29596 & + \\
\hline Phytophthora cinnamomi & Lupinus angustifolius & Australia, Queensland, Caboolture & 29597 & + \\
\hline Phytophthora cinnamomi & Eucalyptus gummifera & Australia, NSW, Kioloa & 29606 & + \\
\hline Phytophthora cinnamomi & Unknown & Australia, NSW, Murwilumbah & 29608 & + \\
\hline Phytophthora cinnamomi & Persea americana & South Africa, Limpopo, Tzaneen & $\ldots$ & + \\
\hline Phytophthora cinnamomi & Persea americana & South Africa, Limpopo, Tzaneen & $\ldots$ & + \\
\hline Phytophthora cinnamomi & Persea americana & South Africa, Limpopo, Tzaneen & $\ldots$ & + \\
\hline Phytophthora cinnamomi & Persea americana & South Africa, Limpopo, Tzaneen & $\ldots$ & + \\
\hline Phytophthora cinnamomi & Persea americana & South Africa, Kwazulu-Natal, Howick & $\ldots$ & + \\
\hline Phytophthora cinnamomi & Persea americana & South Africa, Kwazulu-Natal, Howick & $\ldots$ & + \\
\hline Phytophthora cinnamomi & Persea americana & South Africa, Kwazulu-Natal, Howick & $\ldots$ & + \\
\hline Phytophthora cinnamomi & Persea americana & South Africa, Kwazulu-Natal, Howick & $\ldots$ & + \\
\hline Phytophthora alticola & Eucalyptus bajensis & South Africa, Kwazulu-Natal, Midi Illovo & 26295 & _- \\
\hline Phytophthora alticola & Eucalyptus bajensis & South Africa, Kwazulu-Natal, Paulpietersburg & 26296 & - \\
\hline Phytophthora arecae & Unknown & South Africa, Western Cape, Stellenbosch & 19436 & _- \\
\hline Phytophthora arecae & Unknown & South Africa, Western Cape, Stellenbosch & 19437 & - \\
\hline Phytophthora boehmeriae & Eucalyptus smithii & South Africa, Kwazulu-Natal, Howick & 19440 & - \\
\hline Phytophthora boehmeriae & Eucalyptus smithii & South Africa, Kwazulu-Natal, Ixopo & 19439 & _- \\
\hline Phytophthora cactorum & Cussoniapaniculata & South Africa, Northern Cape, Krugersdorp & 1259 & - \\
\hline Phytophthora cactorum & Apple seedling rootstock & South Africa, Western Cape, Grabouw & 1260 & _- \\
\hline Phytophthora citricola & Lucerne & South Africa, Northern Cape, Kimberley & 1264 & - \\
\hline Phytophthora citricola & Lemonshoots/eureka & South Africa, Western Cape, Paarl & 1265 & _- \\
\hline Phytophthora citrophthora & Citrus rootstock & South Africa, Limpopo, Letaba Estate & 20206 & _- \\
\hline Phytophthora citrophthora & Citrus rootstock & South Africa, Western Cape & 20204 & - \\
\hline Phytophthora colocasiae & $\ldots$ & Unknown & 20201 & _- \\
\hline Phytophthora colocasiae & Protea & South Africa, Western Cape & 22018 & - \\
\hline Phytophthora crytogea & Vitis vinifera & South Africa, Western Cape & 19411 & _- \\
\hline Phytophthora crytogea & Pinus sp. & South Africa, Western Cape & 19410 & - \\
\hline Phytophthora drechsleri & Solanum tuberosum & Argentina, Cordoba & 28869 & - \\
\hline Phytophthora drechsleri & Beta vulgaris & USA, California & 28870 & _- \\
\hline Phytophthora eucalypti sp. nov. & Eucalyptus sp. & South Africa, Kwazulu-Natal, Ingwe & 22024 & - \\
\hline Phytophthora eucalypti sp. nov. & Eucalyptus smithii & South Africa, Kwazulu-Natal & 22029 & _- \\
\hline Phytophthora foliorum & Azalea & USA, Tennessee & 31064 & - \\
\hline Phytophthora frigida & Eucalyptus smithii & South Africa, Kwazulu-Natal, Lion River & 19433 & _- \\
\hline Phytophthora frigida & Eucalyptus smithii & South Africa, Kwazulu-Natal, Pietermaritzburg & 19434 & - \\
\hline Phytophthora humicola & Soil from citrus orchards & Taiwan, Changhua, Yungching & 28866 & - \\
\hline Phytophthora humicola & Citrus & Taiwan & 28867 & - \\
\hline Phytophthora inundata & Aesculus hippocampus & UK, Buckinghamshire, Claydon & 29595 & - \\
\hline Phytophthora megasperma & Medicagosativa & Canada, Ontario, Dundas County & 28865 & - \\
\hline Phytophthora megasperma & Medicagosativa & Canada, Ontario, Dundas County & 28864 & - \\
\hline Phytophthora multivora & Soil & South Africa, KZN, Umtamvuna Nature Reserve, Port Edward & 35209 & - \\
\hline Phytophthora multivora & Soil & South Africa, KZN, Umtamvuna Nature Reserve, Port Edward & 35210 & - \\
\hline Phytophthora nicotianae & Citrus sp. & South Africa, Limpopo, Tzaneen & 19442 & - \\
\hline Phytophthora nicotianae & Acacia mearnsii & South Africa, Kwazulu-Natal, Lion River & 19443 & - \\
\hline Phytophthora palmivora & Kentia palm & Australia, Queensland, Caboolture & 29599 & - \\
\hline Phytophthora palmivora & Arecastrumroman zoffianum & Australia, Queensland, Pimpama & 29601 & _- \\
\hline Phytophthora parasitica & Acacia mearnsii & South Africa, Mpumalanga, Tygerkloof/Piet Retief & 1521 & - \\
\hline Phytophthora parasitica & Acacia mearnsii & South Africa, Mpumalanga, Tygerkloof/Piet Retief & 1522 & - \\
\hline Phytophthora pgchlamydo & River & South Africa, KZN, Ingeli Forest, Weza & 35258 & _- \\
\hline Phytophthora pgchlamydo & River & South Africa, KZN, Ingeli Forest, Weza & 35257 & - \\
\hline Phytophthora quininea & Cinchona officinalis & Peru, Region of Tingo Maria & 31061 & _- \\
\hline Phytophthora quininea & Cinchona officinalis & Peru, Region of Tingo Maria & 31062 & - \\
\hline
\end{tabular}

${ }^{\mathrm{a}} \mathrm{CMW}=$ Culture collection of the Forestry and Agricultural Biotechnology Institute, University of Pretoria, South Africa and PCR = polymerase chain reaction. 
a fine powder with a homogenizer (IKA A11 Basic analytical mill; United Scientific [Pty.] Ltd.), and stored at $-80^{\circ} \mathrm{C}$. The experiment was repeated.

DNA extractions from mycelia and plant tissues. DNA from pure Phytophthora cultures was extracted by using PrepMan Ultra Reagent (Applied Biosystems). Mycelia (approximately $50 \mathrm{mg}$ ) were placed in a 1.5-ml Eppendorf tube together with $100 \mu \mathrm{l}$ of PrepMan Ultra Reagent. The tubes were heated for $5 \mathrm{~min}$ at $95^{\circ} \mathrm{C}$, after which the mycelia were homogenized in the tube by using a micropestle and further incubated for $5 \mathrm{~min}$ at $95^{\circ} \mathrm{C}$, followed by centrifugation for $10 \mathrm{~min}$ at $10,000 \mathrm{rpm}$. Supernatant was collected and diluted five times with sterile water and kept at $-20^{\circ} \mathrm{C}$ until further use. The concentration of all DNA samples was determined using a Nanodrop ND-100 Spectrophotometer (Nanodrop Technologies, Inc.). DNA from infected avocado root material was extracted following the method described by Brunner et al. (1).

Primer design and pathogen quantification. The amount of plant genomic DNA present within each sample was quantified by real-time PCR using primers amplifying a portion of the avocado Actin gene. The primers Actin-fwd (5'-GTATTCATTCACCAC TACTG-3') and Actin-rev (5'-AGTCAAGAGCCACATAAG-3') were designed based on a Persea americana Actin sequence (GenBank accession number GU272027). A normal one-step real-time PCR was used for the plant Actin gene. The amount of plant DNA was calculated based on a standard curve constructed from different known amounts of avocado genomic DNA.

The amount of $P$. cinnamomi DNA present within samples was quantified using a nested real-time PCR approach. This helps to increase the sensitivity of the assay because the detection of pathogen DNA in the early stage of infection can be problematic due to the low concentrations of pathogen DNA. Attempts to use YPh1-fwd (5'-CGACCATKGGTGTGGACTTT-3') and YPh1-rev (5'-ACGTTCTCMCAGGCGTATCT-3') as outer primers and Ycinfwd (5'-GTCCTATTCGCCTGTTGGAA-3') and Ycin-rev (5'GGTTTTCTCTACATAACCATCCTATAA-3') as inner primers developed by Schena et al. (13) did not yield reliable results in this study. Therefore, we selected $L p v$, which encodes putative storage proteins in zoospores of $P$. cinnamomi, as the target gene for pathogen quantification (10). Primers for the first-round PCR (outer PCR) were LPV3-fwd (5'-GTGCAGACT GTCGATGTG-3') and LPV3-rev (5'-GTGCAGACTGTCGAT GTG-3'), as developed by Kong et al. (7). Primers for the second-round nested PCR, LPV3N-fwd (5'-GTGCAGACTGTCGATGTG-3') and LPV3N-rev (5'-GAGGTGAAGGCTGTTGAG-3'), were designed to bind within the outer PCR product based on the alignment of LPV3 genes from several P. cinnamomi isolates infecting avocado and eucalyptus. The outer PCR was carried out as a conventional PCR with only 15 cycles, using the LPV3-fwd and LPV3-rev primers. The second real-time nested PCR was carried out using primers LPV3N-fwd and LPV3N-rev, with the outer PCR product as template. The amount of pathogen DNA was calculated based on a standard curve constructed from different known amounts of $P$. cinnamomi DNA.

PCR protocols. Conventional PCR (as for LPV3 outer PCR). PCR reactions were carried out in a total volume of $25 \mu$ containing $2.5 \mu \mathrm{l}$ of $10 \times \mathrm{PCR}$ reaction buffer, $2.5 \mathrm{mM} \mathrm{MgCl}_{2}, 200 \mu \mathrm{M}$ each dNTP, $0.2 \mu \mathrm{M}$ each specific primer, $1 \mathrm{U}$ of Fast Start Taq DNA polymerase (Roche Applied Science), and 20 to $50 \mathrm{ng}$ of template DNA. Amplification conditions were as follows: $95^{\circ} \mathrm{C}$ for $5 \mathrm{~min}$; followed by 15 cycles at $95^{\circ} \mathrm{C}$ for $30 \mathrm{~s}, 55^{\circ} \mathrm{C}$ for $30 \mathrm{~s}$, and $72^{\circ} \mathrm{C}$ for $30 \mathrm{~s}$; with a final elongation step at $72^{\circ} \mathrm{C}$ for $10 \mathrm{~min}$. Amplifications were performed in an Eppendorf Master Cycler gradient (Eppendorf).

Quantitative real-time PCR. Quantitative real-time PCR was performed using the Bio-Rad CFX 96 instrument (Bioline Ltd.). A 20- $\mu \mathrm{l}$ reaction for PCR amplification contained $10 \mu \mathrm{l}$ of Sensimix SYBR No-ROX (Bioline Ltd.), $0.25 \mu \mathrm{M}$ each forward and reverse primer, $2 \mu \mathrm{l}$ of template $(2 \mu \mathrm{l}$ of first-round PCR product was used as template in the case of LPV3), and $3 \mu$ of PCR-grade water. Thermal cycling conditions for actin were as follows: preincubation for $10 \mathrm{~min}$ at $95^{\circ} \mathrm{C}$ (hot start) followed by 40 cycles, each consisting of $15 \mathrm{~s}$ of denaturing at $95^{\circ} \mathrm{C}, 15 \mathrm{~s}$ of annealing at $60^{\circ} \mathrm{C}$, and $15 \mathrm{~s}$ of primer extension at $72^{\circ} \mathrm{C}$. Thermal cycling conditions for LPV3N were preincubation for $10 \mathrm{~min}$ at $95^{\circ} \mathrm{C}$ (hot start) followed by 40 cycles, each consisting of $5 \mathrm{~s}$ of denaturing at $95^{\circ} \mathrm{C}, 5$ $\mathrm{s}$ of annealing at $60^{\circ} \mathrm{C}$, and $5 \mathrm{~s}$ of primer extension at $72^{\circ} \mathrm{C}$. Negative controls contained water as template. All PCR reactions were performed in triplicate on each of the three biological replicates of two separate experiments. Melting curves were acquired at the end of the PCR run over the range of 65 to $95^{\circ} \mathrm{C}$, increasing the temperature stepwise by $0.5^{\circ} \mathrm{C}$ every $5 \mathrm{~s}$ to confirm that individual qPCR signals corresponded to a single homogenous DNA product. For assessment of PCR success and specificity, PCR products were separated by electrophoresis using $2 \%$ agarose gels, stained with GelRed (Biotium, Inc.) and visualized under UV light.

Statistical analysis. Standard regression curves were calculated from amplification data from the serial dilutions as follows: $y=m x+$ $b$, where $b=y$-intercept of standard curve line (crossing point) and $m$ = slope of the standard curve line (function of PCR efficiency) (6). All statistical analyses were conducted with the Statistics Online Computational Resource software. A Shapiro-Wilk normality test was performed prior to a Mann-Whitney unpaired $t$ test.

\section{Results}

Primer design. Real-time primer pairs designed for actin and LPV3N consistently amplified the expected single bands of $77 \mathrm{bp}$

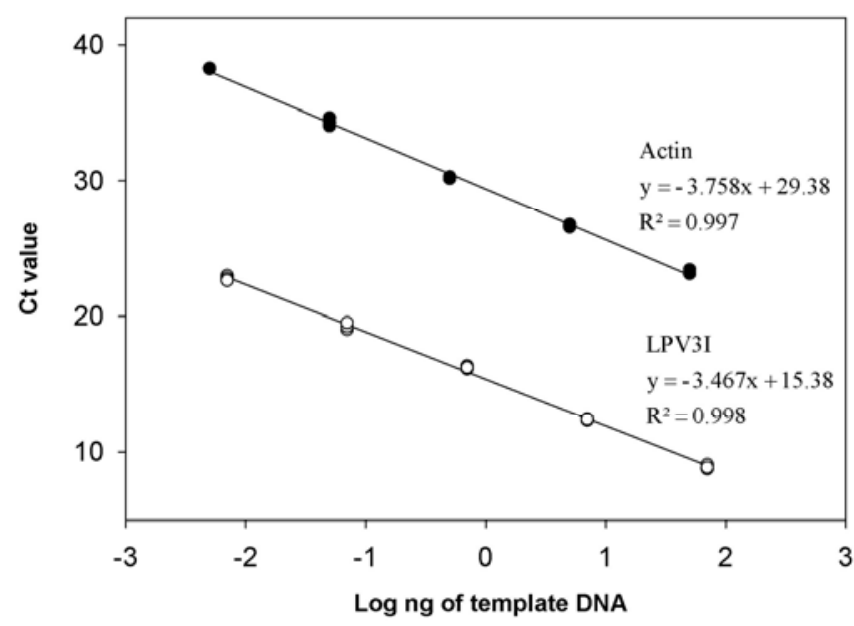

Fig. 1. Standard regression curve plots to assess the sensitivity of the quantitative polymerase chain reaction assay. A dilution series of avocado and Phytophthora cinnamomi DNA spanning five orders of magnitude $(1: 0,1: 10,1: 100,1: 1,000$, and 1:10,000) amplified with Actin and LPV3N was used to generate standard curves for each separate primer pair.

Table 2. Polymerase chain reaction primers used in this study, their target genes, and product information

\begin{tabular}{llcc}
\hline Primer name & \multicolumn{1}{c}{ Sequence $\left(\mathbf{5}^{\prime} \rightarrow \mathbf{3}^{\prime}\right)$} & Target gene & Product size $(\mathbf{b p )}$ \\
\hline LPV3-for & GTGCAGACTGTCGATGTG & Lpv3 & 450 \\
LPV3-rev & GAACCACAACAGGCACGT & Lpv3 & $\ldots$ \\
LPV3N-for & GTCACGACCATGTTGTTG & Lpv3 & 77 \\
LPV3N-rev & GAGGTGAAGGCTGTTGAG & Lpv3 & $\ldots$ \\
Actin-for & GTATTCATTCACCACTACTG & Actin & 77 \\
Actin-rev & AGTCAAGAGCCACATAAG & Actin & This study \\
\hline
\end{tabular}


for both products (Table 2). No cross amplification was observed when actin primers were tested on $P$. cinnamomi DNA or when LPV3N primers were tested on $P$. americana DNA.

PCR efficiencies and linearity. Known concentrations of 10fold serially diluted DNA from $P$. cinnamomi and $P$. americana were used to construct standard curves (Fig. 1). Primer pairs showed high qPCR efficiency rates with high linearity (Fig. 1). Standard curves indicated consistent amplification over the different concentrations of template DNA used.

Sensitivity and specificity. To determine the sensitivity of the assay, a conventional and nested PCR was performed using different amounts of $P$. cinnamomi DNA, ranging from $200 \mathrm{ng} / \mu \mathrm{l}$ to 2 $\mathrm{ag} / \mu \mathrm{l}$. The lowest concentration detected using conventional PCR was 20 pg (Fig. 2). When nested PCR was used, the detection limit was decreased to $20 \mathrm{fg}$, a 1,000-fold enhancement of detection sensitivity.

The specificity of the assay was tested with DNA samples from 21 Phytophthora spp. (one to two isolates per species were tested) by PCR using LPV3N-fwd and LPV3N-rev primers. The results showed that LPV3N-fwd and LPV3N-rev primers were specific for

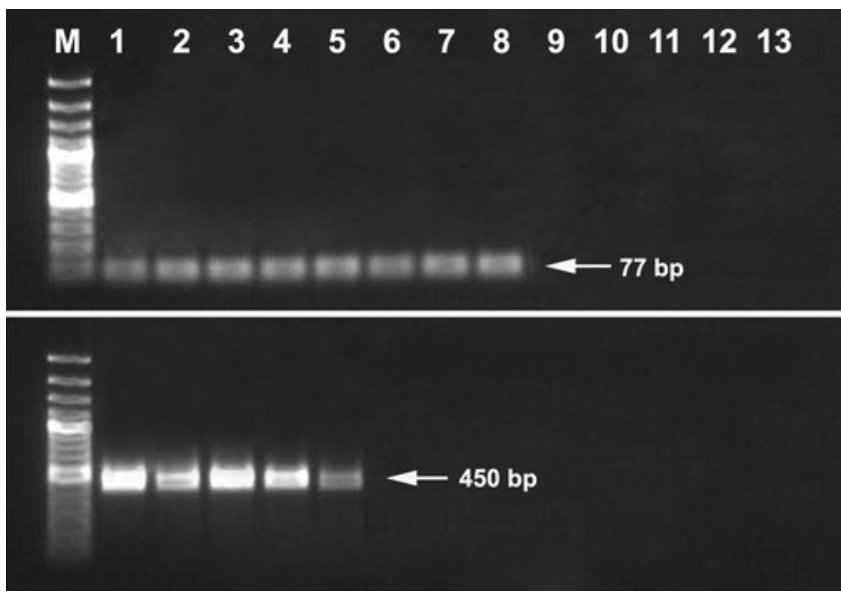

Fig. 2. Top: sensitivity analysis of nested polymerase chain reaction (PCR) for Phytophthora cinnamomi. The first-round PCR was performed using LPV3 as primer pair and indicated amounts of $P$. cinnamomi DNA as template. The secondround PCR was performed using LPV3N as primer pair and amplified products from first-round PCR were used as template. Amplification products were analyzed by gel electrophoresis. Lane M: 100-bp ladder; lane 1: $200 \mathrm{ng}$; lane 2: $20 \mathrm{ng}$; lane 3: 2 ng; lane 4: $200 \mathrm{pg}$; lane 5: $20 \mathrm{pg}$; lane 6: 2 pg; lane 7: $200 \mathrm{fg}$; lane 8: $20 \mathrm{fg}$; lane 9: $2 \mathrm{fg}$; lane 10: $200 \mathrm{ag}$; lane 11: water control. Bottom: sensitivity analysis of conventional PCR for $P$. cinnamomi. Amplification products were analyzed by gel electrophoresis. Lane M: 100-bp ladder; lane 1: $200 \mathrm{ng}$; lane 2: $20 \mathrm{ng}$; lane 3: $2 \mathrm{ng}$; lane 4: 200 pg; lane 5: 20 pg; lane 6: 2 pg; lane 7: 200 fg; lane 8: 20 fg; lane 9: 2 fg; lane 10: 200 ag; lane 11: water control.
$P$. cinnamomi and only produced a fragment of $77 \mathrm{bp}$ for all $P$. cinnamomi isolates. No cross-amplification was observed with other Phytophthora spp. (Table 1). Additionally, melting curve analysis of real-time PCR products resulted in single dissociation peaks with specific melting temperatures for LPV3N (at $82^{\circ} \mathrm{C}$ ) and actin $\left(\right.$ at $77^{\circ} \mathrm{C}$ ), confirming that the primers were specific for their target sequences (Fig. 3).

In planta monitoring of $P$. cinnamomi. The growth of $P$. cinnamomi was assessed for 3 weeks in inoculated avocado rootstocks by qPCR. Total genomic DNA was extracted from infected root materials which contained both plant and pathogen DNA. The amount of plant DNA was quantified by using primers (Actin-fwd and Actin-rev) specific for the avocado actin gene. For quantification of $P$. cinnamomi DNA, primers (LPV3-fwd, LVP3-rev, LPV3N-fwd, and LPV3N-rev) were used in a nested real-time PCR. Pathogen load was determined by comparing the amount of pathogen DNA with the amount of plant DNA for each individual sample.

The quantitative nested PCR was sensitive enough to detect pathogen DNA at all time points except for the noninoculated control $(0 \mathrm{dpi})$. The trend of the ratio of $P$. cinnamomi DNA per plant DNA over the different time points was the same for the highly tolerant rootstock (Dusa) and the less-tolerant rootstock (R0.12); however, the amount of $P$. cinnamomi DNA was significantly higher in R0.12 at all time points $(P<0.001)$ (Fig. 4). In both the highly tolerant (Dusa) and less-tolerant (R0.12) rootstocks, the amount of $P$. cinnamomi DNA increased over a 7-day period post inoculation. Between 7 and $21 \mathrm{dpi}$, the amount of $P$. cinnamomi DNA declined. However, at 21 days, there was detectable DNA in both rootstocks.

A significantly higher ratio of $P$. cinnamomi DNA to plant DNA in the susceptible R0.12 at each time point was present when compared with the highly tolerant Dusa. Visual observations showed similar results. R0.12 roots had more necrotic lesions and were black and brittle compared with the tolerant Dusa (Fig. 5).

\section{Discussion}

A nested real-time PCR was developed that allowed specific, sensitive, and quantitative detection of $P$. cinnamomi within root tissues of avocado. This assay was highly sensitive, with detection limits as low as $20 \mathrm{fg}$ of $P$. cinnamomi DNA. This is an improvement in sensitivity versus other DNA-based detection methods for P. cinnamomi, where $100 \mathrm{fg}$ could be detected (13).

Primers (LPV3-fwd and LPV3-rev) for the Lpv3 gene previously designed by Kong et al. (7) successfully amplified a portion of the Lpv 3 gene from P. cinnamomi with a detection limit up to $20 \mathrm{pg}$ of $P$. cinnamomi DNA. By designing a second pair of primers (LPV3N-fwd and LPV3N-rev), nested within the first PCR product, and using these two primer pairs together in a nested PCR system, we were able to increase the sensitivity of the assay to
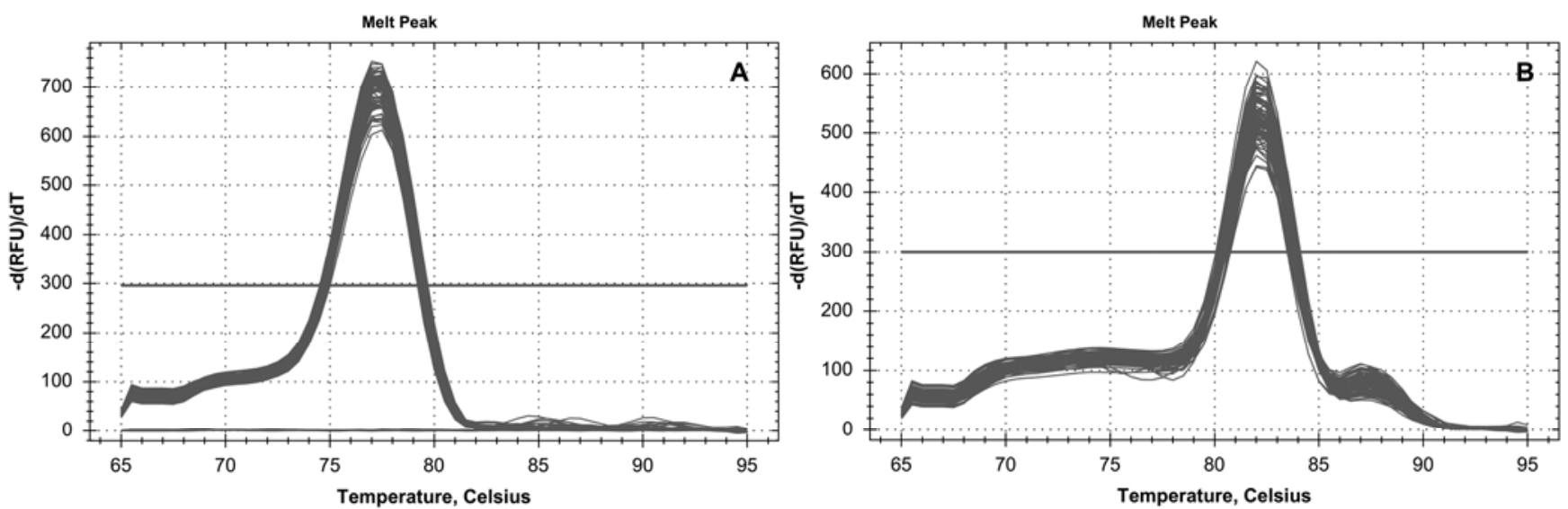

Fig. 3. Melting curve analysis for A, actin and B, LPV3N samples assayed by quantitative polymerase chain reaction (qPCR). The negative first derivative of the normalized fluorescence was plotted against the temperature to determine the melting temperature $\left(T_{m}\right)$ of the amplicons generated during $q P C R$ analysis. 


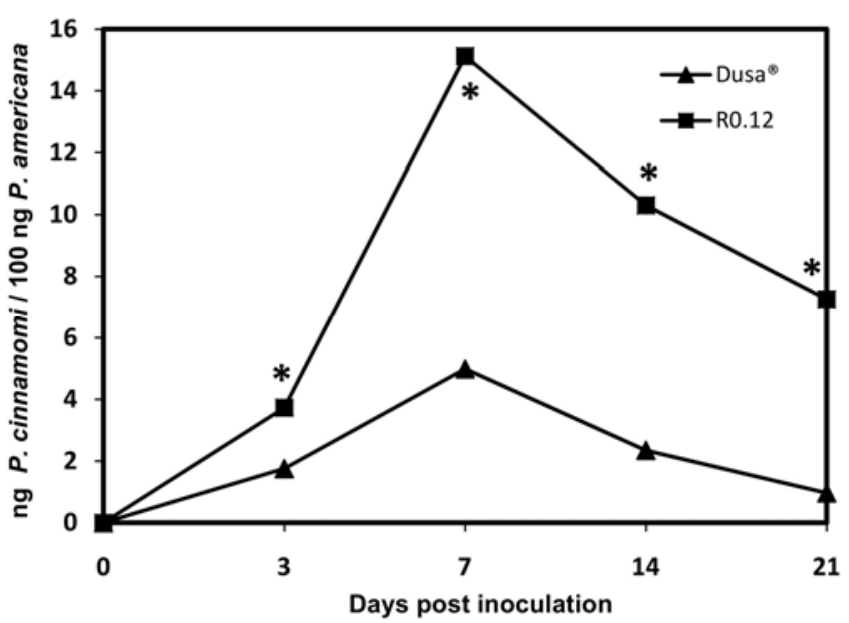

Fig. 4. Monitoring of Phytophthora cinnamomi growth by quantitative polymerase chain reaction in inoculated avocado root tissues. Pathogen load was quantified from infected root tissues by normalizing the LPV3N values with the corresponding actin values for each individual sample. Data were analyzed with the Statistics Online Computational Resource software package using a Mann-Whitney unpaired $t$ test (at each time point, $P<0.001$ ).

detect as little as $20 \mathrm{fg}$ of $P$. cinnamomi DNA. The Lpv 3 gene, which encodes for a putative storage protein in the large peripheral vesicles in zoospores of $P$. cinnamomi, consists of 12 to 18 highly conserved 534-bp repeat units (9). Placing primers in this unique repetitive unit improved the specificity and sensitivity of detection for this species. The nested primer pairs designed by Schena et al. (13), which were based on a single-copy gene (the ras-related protein gene Ypt1), did not amplify any product when DNA from infected avocado root tissue was used. However, because these primer pairs have only been used to detect $P$. cinnamomi DNA from pure cultures, they may not be sufficiently sensitive for use with infected plant tissue (13).

In this study, the amount of pathogen DNA was directly normalized with the host plant DNA and, therefore, provided accurate and reliable results when compared with techniques that are based on detection of pathogen DNA only. The effect of varying amounts of starting material as well as any PCR inhibitor present in the sample was standardized for both plant and pathogen DNA. Moreover, the use of a plant actin gene also served as an internal control to eliminate false-negative results. $P$. cinnamomi is known to be a hemibiotroph; thus, one would expect plant DNA to be degraded when the infection becomes necrotrophic, and this would give biased results toward pathogen DNA. For example, with the necrotic fungus $B o$ trytis cinerea on grape, Diguta et al. (3) noted inaccuracy of pathogen quantification when normalizing to host DNA. The correlation between the amount of pathogen DNA in relation to plant DNA and susceptibility should be well maintained. This biased effect toward pathogen DNA in a necrotrophic system can be overcome by spiking foreign DNA in the extraction protocol to use it as a normalization parameter, as has been shown in various studies $(3,4)$.

The maximum amount of $P$. cinnamomi DNA in infected roots was observed at $7 \mathrm{dpi}$ for both the highly tolerant (Dusa) and lesstolerant (R0.12) rootstock. After $7 \mathrm{dpi}$, the ratio of pathogen DNA in relation to plant DNA was reduced. This could be due to the elimination of pathogen biomass in the dead tissue as well as to the generation of new roots from the plants.

In this study, the amount of $P$. cinnamomi DNA in avocado roots as determined by real-time PCR correlated well with the known level of tolerance for these two rootstocks. The amount of $P$. cinnamomi DNA in roots of highly tolerant Dusa was significantly lower $(P<0.001)$ when compared with that of the less-tolerant R0.12 at all time points. Pathogen DNA quantified in roots ranged from 3.73 to $15.12 \mathrm{ng}$ per every $100 \mathrm{ng}$ of plant DNA for R0.12 and 0.97 to $4.98 \mathrm{ng}$ per every $100 \mathrm{ng}$ of plant DNA for Dusa, emphasizing the different tolerance levels of these rootstocks.
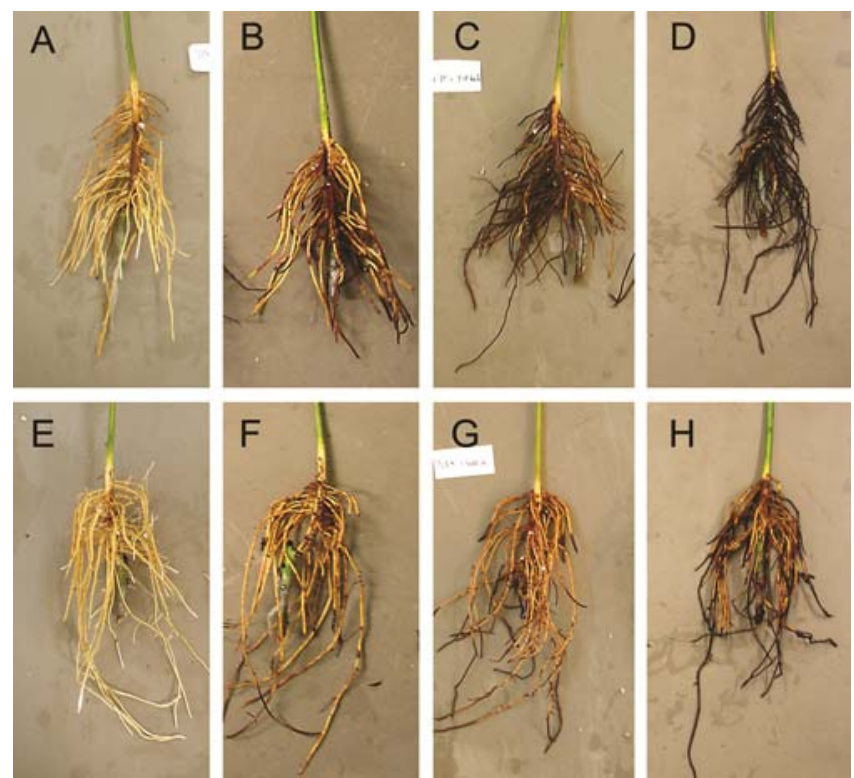

Fig. 5. Root symptoms on Dusa (highly tolerant) and R0.12 (less tolerant) rootstocks after Phytophthora cinnamomi infection. R0.12 roots at $\mathbf{A}, 0$ days post infection (dpi); B, 3 dpi; C, 7 dpi; and D, 14 dpi; and Dusa roots at E, 0 dpi; F, 3 dpi; G, $7 \mathrm{dpi}$; and $\mathbf{H}, 14 \mathrm{dpi}$.

Dan et al. (2) used a PCR-based procedure to differentiate between tolerance and resistance to Verticillium dahliae in potato and suggested that accurate quantification of pathogen biomass in potato should be measured and used as an indicator in breeding for resistance. The quantitative nature of real-time PCR can be very useful in plant breeding programs because it allows comparisons to be made between cultivars with different and even subtle degrees of tolerance or resistance. Our work has proven that this technique is a valuable tool for quantitative pathogen diagnosis as well as for monitoring colonization and disease development. Accurate quantitative measurements of pathogen colonization in host plants is also of great importance because it contributes to a better understanding of the interaction of avocado with P. cinnamomi.

This study provides researchers and the industry with a valuable tool to quantify $P$. cinnamomi in planta. It allows quantification and comparison of the level of infection in avocado rootstocks with varying levels of tolerance. This is the first report that correlates the phenotypic tolerance observed in avocado rootstocks with molecular evidence. This assay has proven to be a useful molecular tool that could be used in breeding programmes where the screening for resistant or highly tolerant varieties against PRR could be sped up and applied in the screening for new anti-oomycete compounds.

\section{Acknowledgments}

This research was funded by the Hans Merensky Foundation and the THRIP program of the National Research Foundation of South Africa. Plant material was provided by Westfalia Technological Services and infrastructure was provided by the University of Pretoria.

\section{Literature Cited}

1. Brunner, I., Brodbeck, S., Büchler, U., and Sperisen, C. 2001. Molecular identification of fine roots of trees from the Alps: reliable and fast DNA extraction and PCR-RFLP analyses of plastid DNA. Mol. Ecol. 10:2079-2087.

2. Dan, H., Ali-Khan, S., and Robb, J. 2001. Use of quantitative PCR diagnostics to identify tolerance and resistance to Verticillium dahliae in potato. Plant Dis. 85:700-705.

3. Diguta, C. F., Rousseaux, S., Weidmann, S., Bretin, N., Vincent, B., and Guilloux-Benatier, M. 2010. Development of a qPCR assay for specific quantification of Botrytis cinerea on grapes. FEMS Microbiol. Lett. 131:8187.

4. Eshraghi, L., Aryamanesh, N., Anderson, J. P., Shearer, B., McComb, J. A., Hardy, G. E. S. J., and O'Brien, P. A. 2011. A quantitative PCR assay for accurate in planta quantification of the necrotrophic pathogen Phytophthora cinnamomi. Eur. J. Plant Pathol. 131:419-430.

5. Gessner, M. O., and Newell, S. Y. 2002. Biomass, growth rate, and produc- 
tion of filamentous fungi in plant litter. Pages 390-408 in: Manual of Environmental Microbiology, 2nd ed. C. J. Hurst, R. L. Crawford, G. Knudsen, M. McInerney, and L. C. Sterzenbach, eds. American Society for Microbiology Press, Washington, DC.

6. Ginzinger, D. G. 2002. Gene quantification using real-time quantitative PCR: An emerging technology hits the mainstream. Exp. Hematol. 30:503512.

7. Kong, P., Hong, C., and Richardson, P. 2003. Rapid detection of Phytophthora cinnamomi using PCR with primers derived from the $L p v$ putative storage protein genes. Plant Pathol. 52:681-693.

8. Li, S., Hartman, G., Domier, L., and Boykin, D. 2008. Quantification of Fusarium solani $\mathrm{f}$. sp. glycines isolates in soybean roots by colony-forming unit assays and real-time quantitative PCR. Theor. Appl. Genet. 117:343-352.

9. Marshall, J., Wilkinson, J., Moore, T., and Hardham, A. 2001. Structure and expression of the genes encoding proteins resident in large peripheral vesicles of Phytophthora cinnamomi zoospores. Protoplasma 215:226-239.

10. Martin, R. R., James, D., and Lévesque, C. A. 2000. Impacts of molecular diagnostic technologies on plant disease management. Annu. Rev. Phytopathol. 38:207-239.

11. Nicolaisen, M., Suproniene, S., Nielsen, L. K., Lazzaro, I., Spliid, N. H., and Justesen, A. F. 2009. Real-time PCR for quantification of eleven individual Fusarium species in cereals. J. Microbiol. Methods 76:234-240.

12. Qi, M., and Yang, Y. 2002. Quantification of Magnaporthe grisea during infection of rice plants using real-time polymerase chain reaction and Northern blot/phosphoimaging analyses. Phytopathology 92:870-876.

13. Schena, L., Duncan, J., and Cooke, D. 2008. Development and application of a PCR-based 'molecular tool box' for the identification of Phytophthora species damaging forests and natural ecosystems. Plant Pathol. 57:64-75.

14. Vandemark, G., and Barker, B. 2003. Quantifying Phytophthora medicaginis in susceptible and resistant alfalfa with a real-time fluorescent PCR assay. J. Phytopathol. 151:577-583.

15. Wallander, H., Nilsson, L. O., Hagerberg, D., and Bååth, E. 2001. Estimation of the biomass and seasonal growth of external mycelium of ectomycorrhizal fungi in the field. New Phytol. 151:753-760. 